\title{
Martínez García, Ana Belén. New Forms of Self-Narration: Young Women, Life Writing and Human Rights. Palgrave Macmillan. 2020, 151 pages.
}

Silvia Pellicer-Ortín (spellice@unizar.es)

Universidad de Zaragoza

A proliferation of life writing in its different manifestations, accompanied by a growing academic interest in autobiography, is so unquestionable that memoir seems to have "become the genre" in the "period around the turn of the millennium" (Gilmore, Limits of Autobiography 1). The turn of the twentieth century has been described as a "post-autobiographical era" (Light 765); the time when the boundaries between fiction and reality have become blurry and the re-construction of traumatised individual and collective identities has led to the emergence of innovative and liminal autobiographical practices. Ana Belén Martínez García's monograph New Forms of SelfNarration: Young Women, Life Writing and Human Rights (2020) appears as a timely and illuminating response to this phenomenon, but it goes a step further in the sense of considering the impact that the digital world has in today's autobiographical genres. In keeping with seminal works in the field of contemporary autobiography, the volume is framed within the specialised collection of Palgrave Studies in Life Writing whose main aim is to respond to the global impact of life writing and look for contributions dealing with non-traditional contexts. Accordingly, Martínez García explores six life-writing projects of contemporary female icons of human rights activism from the Global South, which explains why current discourse on youth activism reverberates throughout the book (Hesford, Douglas, "Ethical Dialogues," and Maguire). Moreover, the case studies analysed share some features that justify their joint analysis: i) all these life writings deploy similar strategic narrative devices; ii) English is the vehicle to reach audiences worldwide; iii) they imply online and offline writing processes; iv) they promote empathy as a means to generate social awareness; v) they provide these activists with a sense of agency; and vi) these girls act as symbols of the human rights movements that they represent - universal education for girls (Malala Yousafazi), North Korean rights (Hyeonseo Lee and Yeonmi Park), the rights of Syrian war refugees (Bana Alabed and Nujeen Mustafa), 
disabled rights (Nujeen Mustafa), and human trafficking (Yeonmi Park and Nadia Murad).

In agreement with current research in the fields of narrative ethics and vulnerability studies, the "Introduction: Life Writing, Human Rights, and Young Women" reasonably draws on the relevance of new forms of communication in the construction of both the autobiographical self and the process of witnessing as well as on the vital appeal to empathy and vulnerability when writing and decoding these works. New Forms of Self-Narration relies on very up-to-date life-writing theories (Schaffer and Smith, and Douglas) which concentrate on the contradictory nature of these narratives. Although they can actively fight for social justice, we should be attentive to the reductionist and neoliberal attempts at homogenizing these testimonies. Martínez García admits that dealing with extremely mediatised texts may be a disadvantage in her study (6). Therefore, she evokes Dominick LaCapra, Martha Nussbaum, and Suzanne Keen in order to suggest that these autobiographical texts should promote a kind of empathy which does not seek the reader to appropriate or over-identify with the other's pain, what LaCapra has defined as "empathic unsettlement" (41). Martínez García also focuses on the two main narrative mechanisms identified in these young activists' projects as key promoters of empathy in their readers/audience - "ambassadorial" and "broadcast strategic empathy" -, thus knowingly relying on Keen's theories about "strategic narrative empathy" applied to life writing. However, a more comprehensive background of the history of autobiography as a genre and the wide range of contemporary autobiographical sub-genres together with some references to indispensable theories in the field, such as Philippe Lejeune's autobiographical pact, would have enriched the author's initial arguments.

Chapter 2, entitled "Malala Yousafazi: Fighting for Girls' Rights via Collaboration and Co-Construction," analyses the vast online and offline life-writing project of Nobel Peace Prize winner (2014) Malala Yousafazi, which has turned her into a renowned activist for the rights of Pakistani girls and the universal girls' access to education. Martínez García calls forth some recent theories in the field of narrative communication about the co-constructed act of writing and reading 
(Dawson, and Phelan) when she emphasises that Malala's life writing has a strong collaborative dimension. Yet the author asserts that her voice emerges as trustworthy thanks to the particular process of "coconstruction" featuring humanitarian life-writing projects like this (Gilmore, Tainted Witness) and the powerful deployment of discursive strategies aimed at generating empathy. Echoing the second-wave feminist motto "the personal is political," Martínez García claims that Malala succeeds in combining the collective and the singular in her self-representation, which has led to the ethical engagement needed for her cause to become global.

The next two chapters approach two North Korean activists who were born in the same village; nevertheless, Chapter 3, "Hyeonseo Lee: Seeking Justice for the North Korean People on Ted.com," and Chapter 4, "Yeonmi Park: North Korean Activist and Instagram Celebrity," display remarkable differences. Hyeonseo Lee, born in 1980, is the oldest of all the young women in this book. She left the country at 17 but it took her ten years to arrive in South Korea. Although she is older, her multimodal interventions encourage the readers/audience to think of her memories as those of a girl, which favours the mechanisms of "strategic narrative empathy" and the image of vulnerability sought by these projects. Understanding Lee's texts as "counter-histories" (Schaffer and Smith 17) that denounce both the indoctrination that she suffered in her country and the human trafficking she could escape in China, Martínez García wisely revisits the intertwining of the individual and collective dimensions of her autobiographical "I". Park, born in 1993, experienced first-hand the North Korean Famine in the 1990s as well as the violation of her human rights when she became a sexual slave as a teenager. In keeping with those well-known theories in the field of Trauma and Memory Studies about the healing role of talking and writing about traumatic experiences (Laub and Podell, Caruth, and LaCapra), Park's memoir In Order to Live (2015) depicts her as a victim who wants to redefine herself as a survivor by using writing as a mechanism to work through her traumas. This process has been described by Henke as "scriptotheraphy" (xii-xiii), and it could be identified in the other five life-writing projects comprised in New Forms of Self Narration. It is at this point that Martínez García brings to the fore some controversial issues surrounding the genre of first-person testimony, since Park's 
narration has been criticised for some inconsistencies, its emotional language and her sensationalist agenda. In reality, I believe these controversial aspects should be further analysed in all the texts included in this book as most of them have been blamed for similar flaws.

The two following chapters address the life-writing projects of young girls writing from and about the Syrian conflict. In Chapter 5, entitled "Bana Alabed: From Twitter War Child to Peace Icon," Bana Alabed's life-writing practices, mainly targeted at criticising the international community's indifference about the Syrian conflict, are studied by paying attention to the fact that she was only seven when the tweets that she posted from the conflict in Aleppo became famous all around the world. Bana became a symbol of a community of oppressed people by displaying a very violent oratory for such a young girl. In fact, her tweets were strongly mediated by her mother, which is read as another example of a "co-constructed I". Chapter 6, "Nujeen Mustafa: Syrian Refugee Defying Labels on TEDx," addresses the case of Nujeen Mustafa, who was 16 years old when she ran away from Syria with her sister pushing her wheelchair. Both her plight for the rights of refugees and disabled people have turned her into an icon. Again, the figure of the girl survivor is exploited in the revised version of her memoir The Girl from Aleppo (2017) which, by beginning with her crossing the Mediterranean, turns this episode into the centre of her life story. Here, Martínez García explores a question that may have already crossed the readers' minds: Can we say that these texts are merely mediatised by transnational agencies, social platforms and publishing houses or should we say that all these agents have commodified them? I believe that this is the central dilemma at the heart of all the study cases in this book, and thus it would deserve a further critical insight. According to Martínez García, the exhaustive reporting of Nujeen's journey, for instance, implies the dangerous "commodification of sensationalized life narratives by Arab and Muslim women" (98); however, the author appreciates the transnational interest in these texts because it demonstrates that they are intrinsic to our contemporary culture.

Chapter 7, "Nadia Murad: Yazidi Survivor's Written vs. Audiovisual Testimony," deals with another Nobel Peace Prize winner, Nadia Murad (2018). Nadia was born in Iraq (1993) and she lost most of her 
Yazidi relatives at the hands of ISIS. She managed to escape captivity and sexual slavery in 2014 and, thanks to the support of famous lawyer Amal Clooney, she has offered public testimony on her community's behalf since then. As has been examined in the previous examples, the description of the traumatic events that she experienced during her imprisonment is the focus of her activism, yet there is something different in her choice of language. She uses an interpreter in her public speeches, understood as a strategy to develop the audience's empathy and restate the value of her Yazidi culture, whereas her writing takes place in English, pointing at her dual activist identity.

Overall, if there is an aim in which Martínez García's book is successful is that of analysing the discursive strategies present in these life-writing projects and understanding them as active promoters of narrative empathy. All these texts make use of a rhetorical repetition of short phrases and a wide display of rhetorical questions along with an empathic style appealing to universal emotions; they include photographs and paratextual connections that increase the emotional bonding with the audience; they display the shifting perspective between the first-person singular and plural to involve the readers/audience in the act of witnessing; and they illustrate the exclusive use of the first name of the activists as a way of branding themselves. Furthermore, even if these autobiographical projects have been the object of the doubts which often accompany women's testimonies (Gilmore, Tainted Witness), and admitting that they result from a process of co-construction in which the media and UN agencies' role is fundamental, the main message behind this book is that these stories have a great potential in promoting global empathy. Thus, the "Conclusion: Victim Girls Becoming Activist Women" highlights the ethical issues that these viral autobiographies arise and acknowledges that the analysis of these texts does not provide a fully optimistic view of digital life-writing projects, whereas the possibilities that these performances offer for the development of new autobiographical practices should be recognised. To conclude, we cannot but congratulate Martínez García on her final invitation, addressed to the scholarly community, to enrich the discussion within the interdisciplinary fields of human rights activism, gender studies and contemporary life writing, which she has succeeded in assembling in New Forms of Self Narration. 


\section{Works Cited}

Caruth, Cathy. Trauma: Explorations in Memory, Johns Hopkins University Press, 1995.

Dawson, Paul. The Return of the Omniscient Narrator: Authorship and Authority in Twenty-First Century Fiction, The Ohio State University Press, 2013.

Douglas, Kate. Contesting Childhood: Autobiography, Trauma and Memory, Rutgers University Press, 2010.

--. "Ethical Dialogues: Youth, Memoir and Trauma." $a / b$ : Auto/Biography Studies, vol. 30, n. 2, 2015, pp. 271-288.

Gilmore, Leigh. The Limits of Autobiography: Trauma and Testimony, Cornell University Press, 2001.

--. Tainted Witness: Why We Doubt What Women Say About Their Lives, Columbia University Press, 2017.

Henke, Suzette A. Shattered Subjects: Trauma and Testimony in Women's Life-Writing, Macmillan, 1998.

Hesford, Wendy S. Spectacular Rhetorics: Human Rights Visions, Recognitions, Feminisms, Duke University Press, 2011.

Keen, Suzanne. "Life Writing and the Empathetic Circle." Concentric: Literary and Cultural Studies, vol. 42, n. 2, 2016, pp. 9-26.

LaCapra, Dominick. Writing History, Writing Trauma, Johns Hopkins University Press, 2001.

Laub, Dori and Daniel Podell. "Art and Trauma." International Journal of Psychonalysis, vol. 76, n. 5, 1995, pp. 991-1005.

Lejeune, Philippe. "The Autobiographical Pact." On Autobiography, edited by P. J. Eakin, University of Minnesota Press, 1989 (1974), pp. 3-30.

Light, Alison. "Writing Lives." The Cambridge History of Twentieth Century Literature, vol. 1, edited by L. Marcus and P. Nicholls, Cambridge University Press, 2004, pp. 751-767.

Maguire, Emma. Girls, Autobiography, Media Gender and Self-Mediation in Digital Economies, Palgrave Macmillan, 2018.

Nussbaum, Martha. Not for Profit: Why Democracy Needs the Humanities, Princeton University Press, 2012.

Phelan, James C. Somebody Telling Somebody Else: A Rhetorical Poetics of Narrative, The Ohio State University Press, 2017.

Schaffer, Kay, and Sidonie Smith. Human Rights and Narrated Lives: The Ethics of Recognition, Palgrave Macmillan, 2004. 